NEPOZNATI I LOŠE DEFINISANI UZROCI SMRTI U MORTALITETU

STANOVNIKA SRBIJE, HRVATSKE, SEVERNE MAKEDONIJE I

SLOVENIJE, U PERIODU OD 2007. DO 2016. GODINE

ORIGINALNI RAD

ORIGINAL ARTICLE

\title{
UNKNOWN AND ILL-DEFINED CAUSES OF DEATH IN THE MORTALITY OF THE POPULATIONS OF SERBIA, CROATIA, NORTH MACEDONIA, AND SLOVENIA, IN THE PERIOD BETWEEN 2007 AND 2016
}

\author{
Nataša Rosić 1 \\ 1 Gradski zavod za javno zdravlje Beograd, Beograd, Srbija" \\ 1 Institute of Public Health of Belgrade, Belgrade, Serbia
}

\section{SAŽETAK}

Uvod: Podaci o uzroku smrti čine kamen temeljac za analizu zdravstvene situacije i bolesti u zemljama, i daju veliki doprinos izgradnji dokaza za zdravstvene politike.

Cilj: Cilj ovog istraživanja je bio da se utvrdi u kojoj meri su u Srbiji, Hrvatskoj, Severnoj Makedoniji i Sloveniji, u desetogodišnjem periodu, između 2007. i 2016. godine, kao osnovni uzrok smrti, korišćene dijagnoze iz grupe - Simptomi, znaci i patološki klinički i laboratorijski nalazi neklasifikovani na drugom mestu (R00-R99), Međunarodne klasifikacije bolesti (MKB - X revizija).

Materijal i metode: U ovom istraživanju korišćene su metode deskriptivne i analitičke statistike. Urađena je analiza podataka o uzrocima smrti (R00-R99 MKB - X revizija) prema polu, tokom desetogodišnjeg perioda (2007 - 2016). Takođe je kao analitički metod korišćena linearna regresija za analizu trenda.

Rezultati: U Srbiji su, u toku desetogodišnjeg perioda, dijagnoze R00-R99 bile među pet najčešćch grupa dijagnoza smrti, odnosno u svakoj godini su zauzimale treće mesto, sa procentualnom zastupljenošću od 4,7\%. U posmatranom periodu, u zemljama iz okruženja, zabeležen je porast stope umrlih lica u Sloveniji, sa najvećom stopom u 2016. godini (19,9), dok se u Hrvatskoj uočava pad stope umrlih lica sa dijagnozama iz grupe XVIII MKB-X (R00-R99). U Makedoniji je stopa imala linearan trend, sa blagim padom u 2012. (52,3) i 2013. godini (58,7). U posmatranom periodu, zapažen je porast stope broja umrlih stanovnika Srbije sa nepoznatim uzrokom smrti, sa naročito visokim stopama u 2009. i 2016. godini. Uporednom analizom utvrđeno je da su R00-R99 dijagnoze više zastupljene u mortalitetnoj statistici Srbije, u odnosu na Sloveniju i Hrvatsku, a manje u odnosu na Severnu Makedoniju.

Zaključak: Potrebne su hitne intervencije u cilju poboljšanja kvaliteta podataka o osnovnom uzroku smrti u potvrdama o smrti. Potrebno je poboljšati podatke 0 mortalitetu i podatke 0 uzrocima smrti u posmatranim zemljama.

Ključne reči: mortalitet, potvrda o smrti, uzroci smrti, MKB-X

\begin{abstract}
Introduction: Data on the cause of death form the cornerstone for analyzing the health situation and disease in countries, and they make a major contribution to building evidence for health policies.

Aim: The aim of this study was to determine the extent to which diagnoses from the group - Symptoms, signs and abnormal clinical and laboratory findings, not elsewhere classified (R00-R99), International Classification of Diseases (ICD - Revision X) were used as the main cause of death in Serbia, Croatia, North Macedonia, and Slovenia in the ten-year period, 2007 - 2016.
\end{abstract}

Materials and methods: Methods of descriptive and analytical statistics were used in this research. An analysis of data on the causes of death (R00-R99 ICD Revision X), by gender, during the ten-year period (2007 - 2016) was performed. Linear regression was also used as an analytical method to analyze the trend.

Results: During the ten-year period, in Serbia, the R00-R99 diagnoses were among the five most common groups of diagnoses of death, i.e., in each year they took third place, with a percentage of $4.7 \%$. In the observed period, in the surrounding countries, there was an increase in the death rate in Slovenia, with the highest rate in 2016 (19.9), while in Croatia there was a decrease in the death rate related to the diagnoses from group XVIII ICD - X (R00-R99). In Macedonia, the rate had a linear trend, with a slight decline in 2012 (52.3) and 2013 (58.7). In the observed period, an increase in the death rate of the population of Serbia with an unknown cause of death was observed, with particularly high rates in 2009 and 2016. Comparative analysis has shown that R00-R99 diagnoses are represented more in the mortality statistics of Serbia than in Slovenia and Croatia, and less than in Northern Macedonia.

Conclusion: Urgent interventions are needed to improve the quality of mortality statistics and data on the causes of death in the described countries.

Key words: mortality, death certificate, causes of death, ICD-X
Autor za korespondenciju:

Nataša Rosić

Gradski zavod za javno zdravlje Beograd

Bulevar despota Stefana 54a, 11000Beograd, Srbija

E-mail: natasa.rosic@zdravlje.org.rs

Primljeno - Received: May 28, 2021;

\author{
Corresponding author: \\ Nataša Rosić \\ Institute of Public Health of Belgrade \\ 54 Bulevar despota Stefana street, 11000 Belgrade, Serbia \\ E-mail: natasa.rosic@zdravlje.org.rs
}

Prihvaćeno - Accepted: June 2, 2021;

Online first: June 25,2021 


\section{UVOD}

Politike i programi za borbu protiv bolesti i povreda zasnivaju se na pravovremenim informacijama o prirodi i obimu zdravstvenih problema. Najčešće korišćeni podaci za potrebe zdravstvenih politika su statistički podaci o broju ljudi koji umiru, i to prema starosti i polu, kao i prema uzroku smrti. Podaci o uzroku smrti čine kamen temeljac za analizu zdravstvene situacije i bolesti u zemljama, i daju veliki doprinos izgradnji baza podataka za zdravstvene politike [1]. Svetska zdravstvena organizacija (SZO) preporučuje izbegavanje korišćenja neutvrđenih i nepoznatih uzroka smrti u potvrdi o smrti, jer se smatra da ta terminologija ne daje informacije o uslovima koji su doveli do smrti [2]. Takođe, postoje sugestije da stopa smrtnosti za smrt koja se pripisuje simptomima, znacima i loše definisanim uzrocima smrti može biti potencijalni pokazatelj pristupa i korišćenja zdravstvenih usluga [3]. Procenat smrti koje su loše definisane ili kod kojih je uzrok smrti nepoznat, jedan je od pokazatelja i samog kvaliteta podataka o uzroku smrti. Pouzdanost ovih podataka je neophodna, ne samo za procenu trendova i varijacija u zdravlju stanovništva, već i za procenu nejednakosti u zdravlju između grupa stanovništva [4].

Mortalitetni podaci obezbeđuju najvažnije zdravstvene pokazatelje za ocenu i poređenje zdravstvenog stanja na lokalnom, državnom i međunarodnom nivou, jer se u svakoj razvijenoj zemlji, kao i u većini zemalja u razvoju, redovno i sveobuhvatno prikupljaju [5]. Takođe, pouzdani i validni podaci o mortalitetu su važni za epidemiološka istraživanja kao i za javno-zdravstvenu politiku i prioritetne ciljeve [6]. Statistika mortaliteta je jedan od osnovnih izvora zdravstvenih informacija i u mnogim zemljama je najpouzdaniji izvor zdravstvenih podataka [7].

Međunarodna klasifikacija bolesti, njena deseta revizija (MKB-X) spada u referentnu klasifikaciju SZO. Šroko je prihvaćena i preporučuje se kao vodič za međunarodno izveštavanje o zdravlju. Svrha MKB je da omogući sistematsko evidentiranje, analizu, tumačenje i poređenje prikupljenih podataka o smrtnosti i obolevanju, u različitim zemljama ili regionima, i za različite vremenske periode [8]. Međunarodna klasifikacija - MKB je podeljena po grupama i ukupno ima 21 grupu. Grupe od I do XVII se odnose na bolesti i druga bolesna stanja, a Grupa XIX na povrede, trovanje i posledice spoljnjih uzroka. Preostale grupe upotpunjuju okvir mogućih stanja obuhvaćenih dijagnostičkim podacima. Grupa XVIII obuhvata simptome, znake i patološke kliničke i laboratorijske nalaze, koji nisu klasifikovani na nekom drugom mestu [8]. Sa tačke gledišta prevencije smrti, važno je prekinuti lanac događaja koji vodi neželjenom ishodu, bolesti, nesposobnosti.

\section{INTRODUCTION}

Policies and programs for fighting diseases and injuries are based on timely information on the nature and scope of health problems. The most commonly used data for the purpose of health policies are statistical data on the number of deceased people, given by age and sex, as well as by cause of death. The data on cause of death represent the cornerstone of the analysis of the health situation and disease in countries, and they greatly contribute to the development of databases for health policies [1]. The World Health Organization (WHO) recommends avoiding the use of undetermined and unknown causes of death in the death certificate, as the belief is that this terminology does not offer information on the conditions that had led to death [2]. Also, there are suggestions that the death rate for deaths attributed to symptoms, signs and ill-defined causes of death may be a potential indicator of access to and use of health services [3]. The percentage of ill-defined deaths or deaths with unknown cause, is one of the indicators of the very quality of the data on the cause of death. The reliability of these data is necessary, not only for the assessment of trends and variations in the population's health, but also for the assessment of inequalities in health among the population groups [4].

Mortality data provide the most important health indicators for the assessment and comparison of the health status, at the local, state, and international levels, since in each developed country, as well as in most developing countries, these data are regularly and comprehensively collected [5]. Also, reliable and valid data on mortality are important for epidemiological research, as well as for public health policy and priority goals [6]. Mortality statistics is one of the basic sources of health-related information, and, in many countries, it is the most reliable source of health-related data [7].

The International Classification of Diseases, Tenth Revision (ICD-X), is reference classification of the WHO. It is widely accepted and recommended as a guidebook for international reporting on health. The purpose of ICD is to enable systematic recording, analysis, interpreting, and comparison of collected data on mortality and morbidity, in different countries or regions, and for different time periods [8]. The ICD is divided into groups and has a total of 21 groups. Groups I to XVII relate to diseases and other states of illness; Group XIX relates to injuries, poisoning, and consequences of external factors. The remaining groups complete the framework of possible conditions covered by diagnostic data. Group XVIII comprises symptoms, signs and abnormal clinical and laboratory findings, not elsewhere classified [8]. From the point of view of death prevention, it is important to break the chain of events which leads to an adverse outcome, illness or disability. 
Najefektivniji javno-zdravstveni cilj je da spreči dejstvo uzročnika. Zbog toga, osnovni uzrok smrti je definisan kao "(a) bolest ili povreda koja je pokrenula niz bolesnih stanja koja su direktno dovela do smrti ili b) okolnosti nesrećnog slučaja ili nasilja koje su uzrokovale smrtonosnu povredu" [9, str. 35, MKB-X, knjiga 2]. Ova pravila obezbeđuju međunarodnu uporedivost podataka o mortalitetu i pomažu u standardizaciji upravljanja nejasnom medicinskom dokumentacijom. Pravilo je da, kada se u potvrdu o smrti unese više od jednog stanja, treba izabrati samo jedno osnovno stanje koje je dovelo do svih drugih. lako postoje pravilnici koji se primenjuju, kada su u pitanju podaci o mortalitetu, međunarodna uporedivost je ipak ograničena, zbog razlika u zdravstvenim sistemima i nacionalno modifikovanim pravilima $[9,10]$.

Sledeća stanja se smatraju nepoznatim i loše definisanim stanjima: MKB-X, R00-R94 ili R95-R99, Grupa XVIII - Simptomi, znaci i patološki klinički nalazi neklasifikovani na drugom mestu (Prilog 1). Kategorije iz ove grupe ne treba koristiti kao šifre za "glavno stanje", osim ako simptom, znak ili nenormalni nalaz nije bio očigledno glavno stanje za lečenje ili ispitivanje u toku epizode lečenja i nije bio povezan sa drugim stanjem koje je lekar označio [11].

Cilj ovog istraživanja je bio da se utvrdi u kojoj su meri, kao osnovni uzrok smrti, korišćene dijagnoze iz grupe - Simptomi, znaci i patološki klinički i laboratorijski nalazi neklasifikovani na drugom mestu (R00-R99), MKB - X revizija. Ova analiza će omogućiti da se uporedi kvalitet podataka o uzroku smrti u našoj zemlji u odnosu na zemlje regiona i to: Hrvatsku, Severnu Makedoniju i Sloveniju, u desetogodišnjem periodu (2007 - 2016).

\section{METODE}

\section{Jedinice posmatranja i ispitivane varijable}

Jedinice posmatranja su: ukupan broj stanovnika, udeo u ukupnom mortalitetu (\%), i stopa umrlih zbog nepoznatih i loše definisanih uzroka smrti (R00-R99 MKB - X revizija) u Srbiji, Hrvatskoj, Severnoj Makedoniji i Sloveniji, u periodu od 2007. do 2016. godine. Prikazani su i rezultati analize trenda podataka o udelu umrlih zbog R00-R99 u ukupnom mortalitetu (\%).

\section{Izvori podataka}

U istraživanju su korišćeni objavljeni podaci Republičkog zavoda za statistiku o mortalitetu stanovnika Srbije [12-15]. Za međunarodno poređenje korišćeni su zvanični podaci mortalitetne statistike Hrvatske [16-17], Makedonije [18,19] i Slovenije [20,21].

\section{Statistička analiza}

U ovom istraživanju, korišćene su metode deskriptivne i analitičke statistike. Urađena je analiza podataka
The most effective public health goal is to prevent the impact of the causative agent. This is why the underlying cause of death is defined as "the disease or injury that initiated the train of events leading directly to death, or the circumstances of the accident or violence which produced the fatal injury" [9, p. 35, ICD-X, Volume 2]. These rules provide for international comparability of data on mortality and help in the standardization of managing unclear medical documentation. The rule is that, when more than one condition is entered into the death certificate, only one underlying condition should be selected as the one leading to all the others. Although there are rulebooks in use, when it comes to mortality data, international comparability is still limited, due to the differences amongst health systems, as well as nationally modified rules $[9,10]$.

The following states are considered unknown and ill-defined: ICD-X, R00-R94 or R95-R99, Group XVIII - Symptoms, signs and abnormal clinical and laboratory findings, not elsewhere classified (Appendix 1). The categories from this group should not be used as codes for the "underlying cause", unless the symptom, sign, or abnormal finding was the obvious underlying condition that was treated and investigated during the treatment episode and was not connected with any other condition marked by the doctor [11].

The aim of this study was to determine the extent of the use of the diagnoses from the group - Symptoms, signs and abnormal clinical and laboratory findings, not elsewhere classified (R00-R99), ICD, Tenth Revision, as the underlying cause of death. This analysis will enable the comparison of the quality of the data on cause of death in our country with that of the other countries in the region: Croatia, North Macedonia, and Slovenia, over a ten-year period (2007 - 2016).

\section{METHODS}

\section{Units of observation and tested variables}

The units of observation are the following: the overall population, the participation in total mortality (\%), and the rate of persons deceased due to unknown and ill-defined causes of death (R00-R99 ICD - Revision X) in Serbia, Croatia, North Macedonia, and Slovenia, in the period 2007 - 2016. The results of the analysis of the data trend regarding the participation of persons deceased due to R00-R99 in overall mortality (\%) is also presented.

\section{Data sources}

Data published by the Statistical Office of the Republic of Serbia on the mortality of the citizens of Serbia were used in the study [12-15]. Official mortality statistics data of Croatia [16-17], North Macedonia $[18,19]$, and Slovenia $[20,21]$ were used for the purpose of international comparison. 
o uzrocima smrti (R00-R99 MKB - X revizija) prema polu, starosti i regionima Srbije, kao i linija trenda i bazični i lančani indeks promene tokom desetogodišnjeg perioda (2007 - 2016). Za analizu trenda korišćena je linearna regresija uz pomoć programa američkog Nacionalnog instituta za karcinome (engl. Joinpoint Regression Trend Analysis Software - Version 4.9.0.0). Najvažniji rezultati istraživanja prikazani su grafički i tabelarno, zatim kroz procente i stope učešća dijagnoza iz grupe R00-R99 MKB-X u mortalitetnoj statistici stanovnika Srbije i zemalja iz regiona, i prodiskutovani su u svetlu relevantne literature.

\section{REZULTATI}

U posmatranom periodu, zapaža se porast stope broja umrlih na 100.000 stanovnika Srbije sa dijagnozom iz grupe MKB XVIII - Simptomi, znaci i patološki klinički i laboratorijski nalazi neklasifikovani na drugom mestu (u nastavku teksta, R00-R99). Najviša stopa se beleži 2009. godine $(72,0 / 100.000)$ kao i 2016. godine (70,6/100.000) (Grafikon 1).

Tokom posmatranog perioda, u Republici Sloveniji, uočen je porast stope umrlih lica od R00-R99, a najveća stopa se uočava u 2016. godini - 19,9/100.000 (Grafikon 2).

U Republici Hrvatskoj, u posmatranom periodu od 2008. do 2015. godine (2015. godina je bila poslednja godina sa dostupnim podacima u vreme izvođenja studije), uočava se pad stope umrlih lica sa dijagnozama iz grupe R00-R99, tako da su vrednosti u 2006. i u 2015. godini bile iste (Grafikon 3).

Od 2007. do 2016. godine, u Republici Severnoj Makedoniji, stopa umrlih lica sa dijagnozom uzroka smrti iz grupe R00-R99 imala je linearan trend, sa blagim padom u 2012. i 2013. godini (Grafikon 4).

U posmatranom periodu, udeo R00-R99 u ukupnom mortalitetu je bio statistički značajno viši u Srbiji

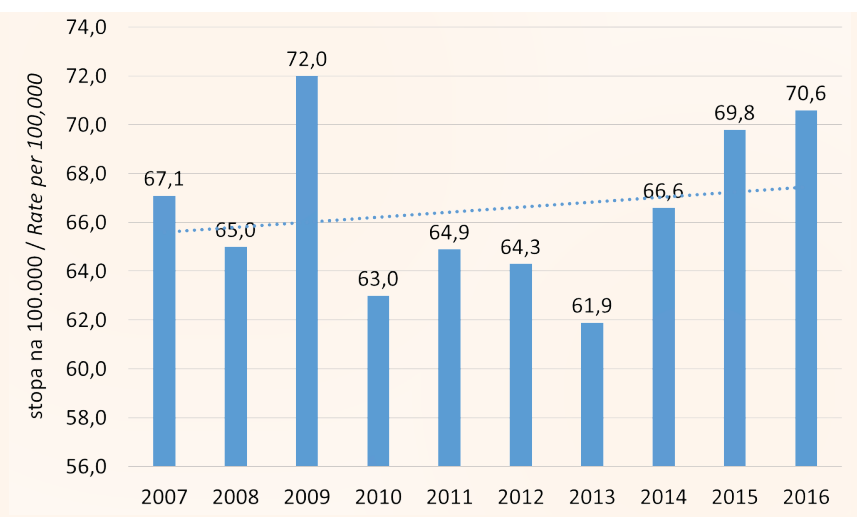

Grafikon 1. Stopa umrlih lica na 100.000 stanovnika sa dijagnozama iz grupe XVIII MKB-X (R00-R99) u Republici Srbiji, od 2007. do 2016. godine

Figure 1. The rate of deceased persons per 100,000 citizens with the diagnosis from the XVIII ICD-X (R00-R99) group, in the Republic of Serbia, between 2007 and 2016

\section{Statistical analysis}

Methods of descriptive and analytical statistics have been used in this study. Analysis of data on the causes of death (R00-R99 ICD - Revision X), by sex, age and regions in Serbia, as well as the trend line, the basic index and the chain index of change, over a ten-year period (2007 - 2016) have been carried out. Linear regression with the support of the program of the American National Cancer Institute (Joinpoint Regression Trend Analysis Software - Version 4.9.0.0) was used for trend analysis. The most significant results of the study are represented in graphs and tables, through percentages and the rate of participation of the diagnoses from the R00-R99 ICD-X group in the mortality statistics of the citizens of Serbia and the countries form the region, and have been discussed in the context of relevant reference literature.

\section{RESULTS}

In the observed period, a rise in the rate of deceased persons per 100,000 citizens of Serbia with a diagnosis from the group ICD XVIII - Symptoms, signs and abnormal clinical and laboratory findings, not elsewhere classified (hereinafter: R00-R99) was recorded. The highest rate was recorded in $2009(72.0 / 100,000)$ as well as in $2016(70.6 / 100,000)$ (Figure 1).

During the observed period, in the Republic of Slovenia, a rise in the rate of persons deceased from R00-R99 was recorded, with the highest rate noted in 2016 - 19.9/100,000 (Figure 2).

In the Republic of Croatia, during the observed period, between 2008 and 2015 (at the time of the study being carried out, year 2015 was the last year with available data), a drop in the rate of deceased persons with diagnoses from the R00-R99 group was recorded, thereby the values in 2006 and 2015 were the same (Figure 3).

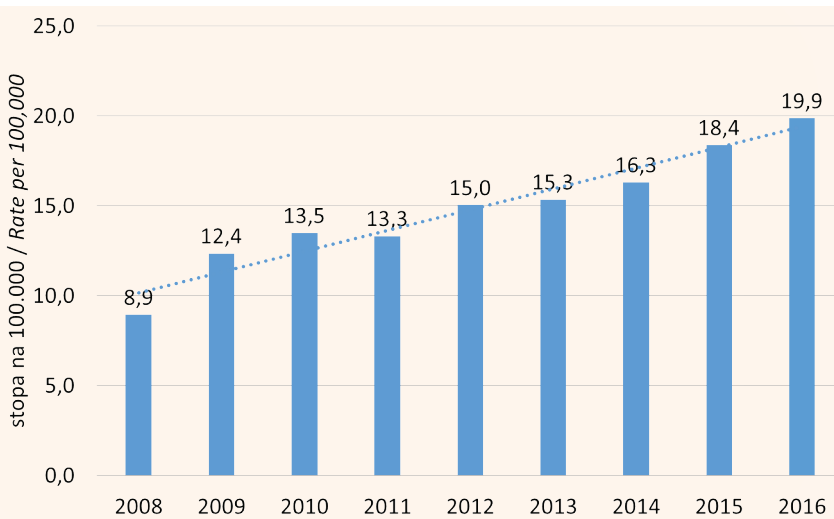

Grafikon 2. Stopa umrlih lica na 100.000 stanovnika sa dijagnozama iz grupe XVIII MKB-X (R00-R99) u Republici Sloveniji, od 2008. do 2016. godine

Figure 2. The rate of deceased persons per 100,000 citizens with the diagnosis from the XVIII ICD-X (RO0-R99) group, in the Republic of Slovenia, between 2008 and 2016 


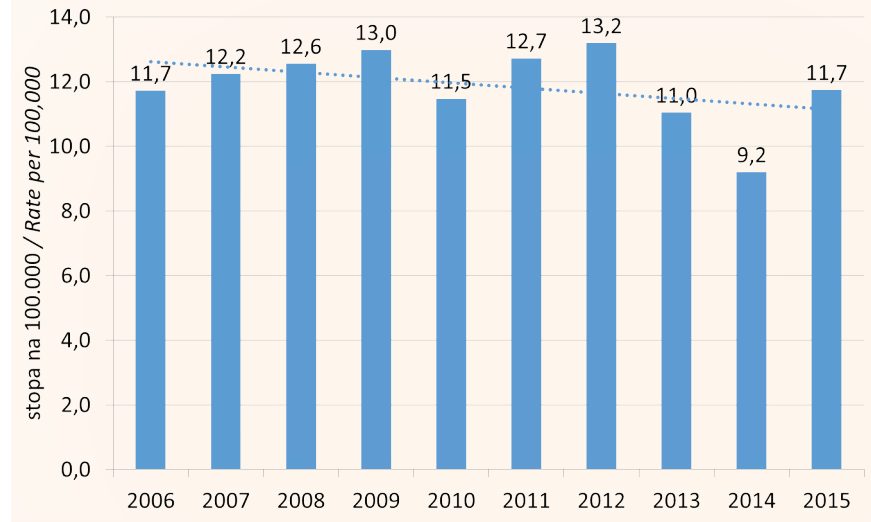

Grafikon 3. Stopa umrlih lica na 100.000 stanovnika sa dijagnozama iz grupe XVIII MKB-X (R00-R99) u Republici Hrvatskoj, od 2008. do 2015. godine

Figure 3. The rate of deceased persons per 100,000 citizens with the diagnosis from the XVIII ICD-X (R00-R99) group, in the Republic of Croatia, between 2008 and 2015

u odnosu na Sloveniju ( $p<0,001)$ (Grafikon 5). U posmatranom periodu, u Srbiji ne postoji statistički značajan trend promena proporcija R00-R99 (APC = 0,0; $p=0,995)$, već linearni stagnantni trend. U Sloveniji postoji statistički značajan linearni trend porasta proporcija R00-R99 u posmatranom periodu sa prosečnom stopom godišnje promene od $6,6 \%$. (APC $=6,6 ; p<0,001)$.

U posmatranom periodu, udeo R00-99 u ukupnom mortalitetu je bio statistički značajno niži u Srbiji u odnosu na Severnu Makedoniju $(p<0,001)$ (Grafikon 6), iako ni u Srbiji ni u Severnoj Makedoniji ne postoji statistički značajan trend promena proporcija R00-R99 u

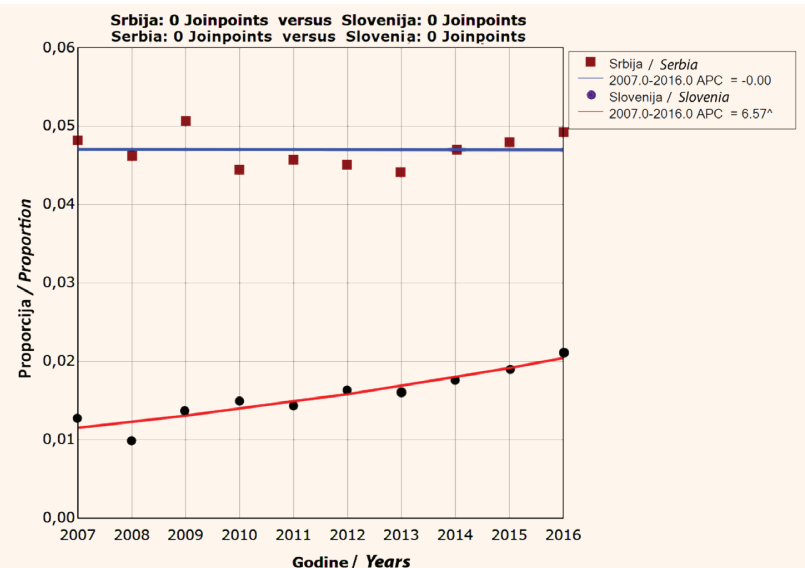

$\hat{\wedge}$ Indicates that the Annual Percent Change (APC) is significantly different from zero at the alpha $=0.05$ level. Final Selected Model: Srbija - 0 Joinpoints, Slovenija - 0 Joinpoints. Rejected Coincidence.

Grafikon 5. Analiza trenda za dijagnoze R00-R99 (Simptomi, znaci i patološki klinički i laboratorijski nalazi neklasifikovani na drugom mestu), poređenje između Republike Slovenije i Republike Srbije, od 2007. do 2016. godine

Figure 5. Trend Analysis for the diagnoses R00-R99 (Symptoms, signs and abnormal clinical and laboratory findings, not elsewhere classified), comparison between the Republic of Slovenia and the republic of Serbia, between 2007 and 2016

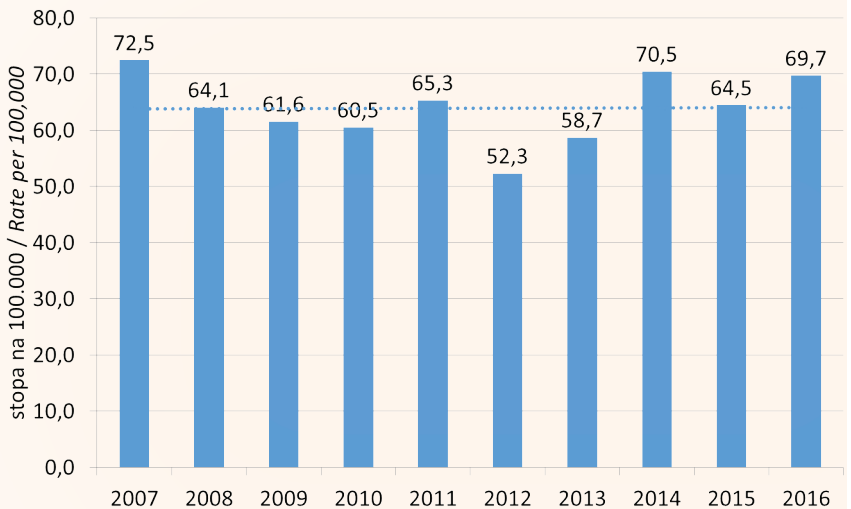

Grafikon 4. Stopa umrlih lica sa dijagnozama iz grupe XVIII MKB-X (R00-R99) u Republici Severnoj Makedoniji, od 2007. do 2016. godine

Figure 4. The rate of deceased persons with the diagnosis from the XVIII ICD-X (R00-R99) group, in the Republic of North Macedonia, between 2007 and 2016

Between 2007 and 2016, in the Republic of North Macedonia, the rate of deceased persons with cause of death diagnoses from the R00-R99 group had a linear trend, with a mild decrease in 2012 and 2103 (Figure 4).

In the observed period, the participation of R00-R99 in the overall mortality was statistically significantly higher in Serbia than in Slovenia $(p<0.001)$ (Figure 5). In the observed period, in Serbia, there is no statistically significant trend of change in the proportion of R00-R99 (APC $=0.0 ; p=0.995$ ), rather, there is a linear trend of stagnation. In Slovenia, within the observed period, there is a statistically significant linear trend of

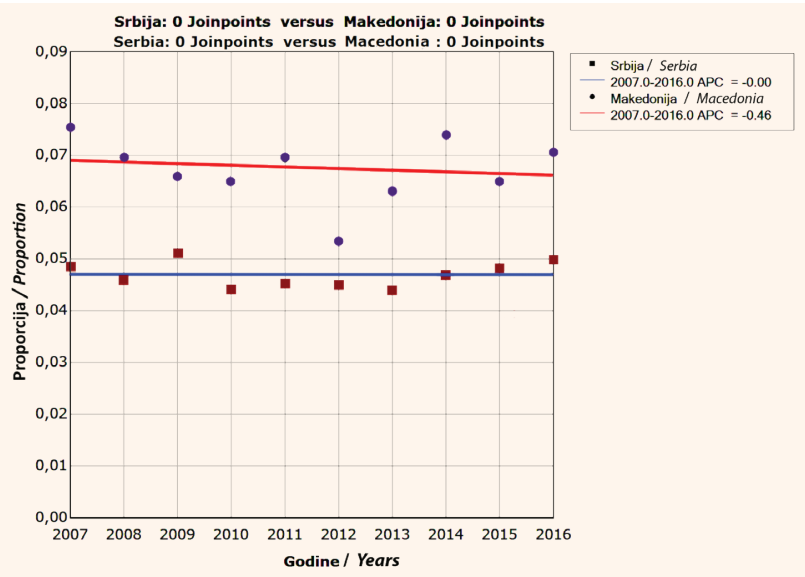

Indicates that the Annual Percent Change (APC) is significantly different from zero at the alpha $=0.05$ level. Final Selected Model: Srbija - 0 Joinpoints, Makedonija - 0 Joinpoints. Rejected Coincidence.

Grafikon 6. Analiza trenda za dijagnoze R00-R99 (Simptomi, znaci i patološki klinički i laboratorijski nalazi neklasifikovani na drugom mestu), poređenje između Republike Srbije i Republike Severne Makedonije, od 2007. do 2016. godine

Figure 6. Analysis of the trend for the diagnoses R00-R99 (Symptoms, signs and abnormal clinical and laboratory findings, not elsewhere classified), comparison between the Republic of Serbia and the Republic of North Macedonia, between 2007 and 2016 


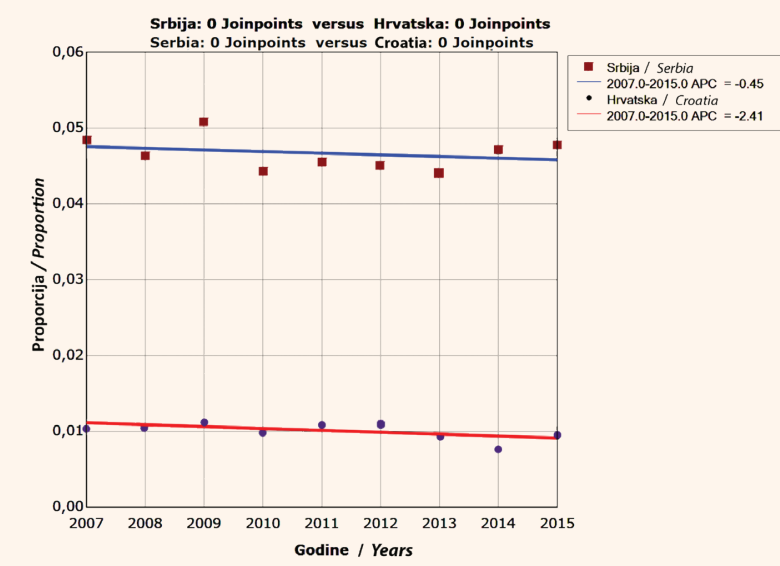

Indicates that the Annual Percent Change (APC) is significantly different from zero at the alpha $=0.05$ level. Final Selected Model: Srbija - 0 Joinpoints, Hrvatska - 0 Joinpoints. Rejected Coincidence.

Grafikon 7. Analiza trenda za dijagnoze R00-R99 (Simptomi, znaci i patološki klinički i laboratorijski nalazi neklasifikovani na drugom mestu), poređenje između Republike Srbije i Republike Hrvatske od 2007. do 2015. godine

Figure 7. Analysis of the trend for the diagnoses R00-R99 (Symptoms, signs and abnormal clinical and laboratory findings, not elsewhere classified), comparison between the Republic of Serbia and the Republic of Croatia, between 2007 and 2015

posmatranom periodu (APC $=0,0 ; p=0,995$ i $\mathrm{APC}=-0,5$; $p=0,669$, respektivno). $\mathrm{U}$ obe zemlje, zastupljen je stabilan linearni trend koji ukazuje na stagniranje i minimalne promene.

Za Hrvatsku su, u vreme istraživanja, bili dostupni samo podaci od 2008. do 2015. godine.

$\mathrm{U}$ tom periodu, vrednosti proporcija R00-R99 su statistički značajno više u Srbiji u odnosu na Hrvatsku $(p<0,001)$ (Grafikon 7). I u Srbiji i u Hrvatskoj postoji linerani trend promena proporcija R00-R99 (APC $=-0,4$; $p=0,464$, i APC $=-2,4 ; p=0,068$, respektivno), odnosno, nema statistički značajnih promena.

\section{DISKUSIJA}

Uprkos preporukama SZO da se izbegava korišćenje neutvrđenih i nepoznatih uzroka smrti u potvrdi o smr$\mathrm{ti}$, jer se smatra da ta terminologija ne daje informacije o uslovima koji su doveli do smrti [3], kao i postojanju zakonske regulative o načinu popunjavanja potvrde o smrti u Srbiji i zemljama u okruženju, u posmatranim zemljama, veliki broj ovih dijagnoza je zastupljen kao osnovni uzrok smrti u potvrdama o smrti. U periodu od 2007. do 2016. godine, u Srbiji, dijagnoze iz grupe XVIII MKB-X (R00-R99) su bile među pet najčešćih grupa dijagnoza navedenih kao osnovni uzrok smrti, odnosno u svakoj godini su prema rangu zauzimale treće mesto, a zabeležen je i njihov porast u 2009. i 2016. godini. Takođe, u posmatranom periodu, postoji porast stope umrlih lica u Sloveniji, gde se najveća stopa uočava u 2016. godini, dok je u Hrvatskoj i Severnoj Makedoniji uočen blagi pad stopa umrlih lica sa dijagnozama R00-R99. increase in the proportion of R00-R99, with an average rate of annual change of $6.6 \%$. (APC $=6.6 ; p<0.001$ ).

In the observed period, the participation of R0099 in the overall mortality was statistically significantly smaller in Serbia than in North Macedonia $(p<0.001)$ (Figure 6), although there isn't a statistically significant trend of change in the proportion of R00-R99, in the observed period, either in Serbia or in North Macedonia $(A P C=0.0 ; p=0.995$ and $A P C=-0.5 ; p=0.669$, respectively). In both countries, a stable linear trend is present, indicating stagnation and minimal change.

At the time of the conducting of the research, there were only data from the period between 2008 and 2015 available for Croatia. In that period the values of the proportion of R00-R99 were statistically significantly greater in Serbia, as compared to Croatia $(p<0.001)$ (Figure 7). There is a linear trend of change in the proportion of R00-R99 (APC $=-0.4 ; p=0.464$, and APC $=-2.4$; $p=0.068$, respectively) both in Serbia and Croatia, i.e., there are no statistically significant changes.

\section{DISCUSSION}

Despite WHO recommendations to avoid the use of undetermined and unknown causes of death in the death certificate, due to the belief that this terminology does not offer information on the conditions that had led to death [3], as well as the existence of legislation regulating the way that the death certificate should be filled out both in Serbia, as well as in the countries from the region, in the observed countries, a large number of these diagnoses is prevalent as the underlying cause of death in the death certificate. In the period between 2007 and 2016, in Serbia, the diagnoses from the group XVIII ICD-X (R00-R99) were amongst the five most common groups of diagnoses stated as the underlying cause of death, i.e., in each year, they were ranked third; also, an increase in their numbers was registered in years 2009 and 2016. Additionally, in the observed period, in Slovenia, there was an increase in the death rate, with the highest rate observed in 2016, while in Croatia and North Macedonia, a mild decrease of death rates of persons diagnosed with R00-R99 as the cause of death was noted.

An increase or continuation of the level of ill-defined causes of death in the mortality statistics represents a great challenge for researchers all over Europe. Experience from other countries teaches us the way to improve data on mortality and cause of death, and, as an example, we can use the fact that the Government of Turkey has, as of 2009, conducted several reforms, at the Turkish Statistical Institute, to improve the system of reporting on the cause of death [22]. After analysis, it has been noted that there is a significant 
Porast ili održavanje nedovoljno definisanih uzroka smrti u mortalitetnoj statistici predstavlja veliki izazov za istraživače širom Evrope. Iskustva iz drugih zemalja nas uče kako bismo mogli da poboljšamo podatke o mortalitetu i uzrocima smrti, a kao primer imamo da je Vlada Turske, od 2009. godine, na Turskom institutu za statistiku, sprovela nekoliko reformi za poboljšanje sistema izveštavanja o uzroku smrti [22]. Nakon analize, uočeno je da u značajnoj meri nedostaju informacije za demografske i epidemiološke varijable, naročito kada su u pitanju smrti odojčadi i detaljno evidentiranje uzroka smrti [22].

Pojava nedovoljno definisanih i loše šifriranih osnovnih uzroka smrti u potvrdi o smrti dovodi do smanjenja korisnosti ovih podataka, naročito kada pristup šifriranju nije standardizovan [23]. Takav je primer iz istraživanja koje ukazuje da u sistemu postoji visok stepen nedoslednosti u šifriranju mentalnih poremećaja i poremećaja ponašanja, bolesti nervnog sistema, endokrinih poremećaja, određenih kardiovaskularnih bolesti i loše definisanih uzroka smrti, kao osnovnog uzroka smrti [23]. U cilju poboljšanja podataka mortalitetne statistike, uvođenje softverskog sistema za šifriranje podataka o uzroku smrti u našoj zemlji bi doprinelo boljem i kvalitetnijem izveštavanju. Od januara 2017. godine, u zemljama EU su u upotrebi softverske verzije MKB-X. Po primeni novog softvera za šifriranje uzroka smrti, Nacionalni registar Škotske registrovao je prvo povećanje, a zatim i smanjenje broja smrti sa određenom dijagnozom kao osnovnim uzrokom smrti [24]. Nacionalni centar za zdravstvenu statistiku američkog Centra za kontrolu i prevenciju bolesti je razvio automatsko šifriranje uzroka smrti, a razvijeni softveri imaju široku primenu, te je smanjen rizik od sistemskih grešaka usled neujednačene interpretacije i primene pravila šifriranja. Softver je na raspolaganju za automatizaciju šifriranja medicinskih informacija na potvrdi o smrti prema uputstvima SZO. Ovo je jedan od retkih izvora podataka vezanih za zdravlje koji su uporedivi za mala geografska područja i dostupni u dugom vremenskom periodu [25].

\section{Ograničenja istraživanja}

Za neke uzroke smrti, statistika mortaliteta je odraz prakse šifriranja, a ne stvarne epidemiološke situacije, te $u$ tom smislu treba posmatrati pouzdanost ovih rezultata istraživanja. Pokrivenost i kvalitet podataka o uzroku smrti variraju između zemalja, i čak validne, pouzdane i uporedive procene trendova uzroka smrti, u najboljim sistemima, ograničene su problemima kao što su promene u MKB-X, upotreba tabelarnih listi u kojima se gube značajni detalji o uzroku smrti, kao i mnogi smrtni slučajevi kojima je kao uzrok smrti dodeljena dijagnoza koja se ne može smatrati osnovnim uzrokom smrti. Naime, podregistracija je naročito ozbiljna lack of data related to demographic and epidemiological variables, especially when it comes to the death of infants and to the detailed recording of the cause of death [22].

The occurrence of ill-defined and poorly coded underlying causes of death in the death certificate undermines the usefulness of this data, especially when the access to coding is not standardized [23]. Such is the example from research indicating that there is a high degree of inconsistency in the system related to the coding of mental disorders and behavioral disorders, diseases of the nervous system, endocrine disorders, certain cardiovascular diseases and ill-defined causes of death, as the underlying cause of death [23]. For the purpose of improving mortality statistics data, the introduction of a software system for the coding of data on the cause of death in Serbia would contribute to better reporting. As of January 2017, software versions of ICD-X have been in use in the EU countries. Upon the implementation of the new software for coding the cause of death, the National Records of Scotland registered the first increase, and then decrease in the number of deaths with a certain diagnosis as the underlying cause of death [24]. The National Center for Health Statistics of the American National Center for Disease Control and Prevention developed an automatic coding system of causes of death, and the developed computer programs are widely in use, which has reduced the risk of systemic errors caused by inconsistent interpretation and application of coding rules. The software is available for the automatization of the coding of medical data in the death certificate, in keeping with WHO guidelines. This is one of the rare sources of health-related data comparable for small geographic areas and available for a longer period of time [25].

\section{Study limitations}

For some causes of death, mortality statistics reflects the coding practice rather than the actual epidemiological situation, and, therefore, the reliability of these research results should be observed in that context. The coverage and quality of data on cause of death vary amongst countries, and even valid, reliable, and comparable assessments of the trends of the cause of death, in the best of systems, are limited by problems such as the changes in the ICD-X, the use of tabular lists where significant details on cause of death are lost, as well as by many deaths which have been assigned a diagnosis that cannot be considered an underlying cause of death. Namely, underregistration is particularly serious in rural areas with poor transport and a poor accessibility to health care centers [26].

It is necessary to research a longer period and a greater number of variables (e.g., by sex, by age, 
u ruralnim područjima, u oblastima sa lošim transportom i slabom dostupnošću zdravstvenih centara [26].

Potrebno je istraživanjem obuhvatiti veći period i veći broj varijabli (na primer, po polu, starosti i pojedinačnim dijagnozama, i po izvoru podataka u potvrdama o smrti), a zatim uraditi uporednu analizu sa dijagnozama obducenata, kako bi se bolje razumeo problem i definisale ciljane intervencije. Zdravstvene ustanove, posebno bolnice, predstavljaju česte izvore podataka o smrtnosti stanovništva prema starosti, polu i uzroku. Ove statistike su važni markeri kvaliteta bolničke nege i obezbeđuju neophodna ulaganja, kako za nacionalne tako i za zdravstvene politike na lokalnom nivou. Neophodna je kontinuirana edukacija, kako lekara u zdravstvenim ustanovama tako i mrtvozornika, koji se bave popunjavanjem potvrde o smrti, o izgledu, sadržaju i pravilnom načinu šifriranja podataka o uzroku smrti. Takođe je veoma važno da donosioci odluka u zdravstvenom sistemu prepoznaju značaj kvalitetnih i tačnih podataka o mortalitetu, te je neophodno ulaganje u jačanje vitalnog sistema registracije, kako bi došlo do poboljšanja na svim nivoima, u smislu ispravno šifriranih osnovnih uzroka smrti i njihovog generisanja u konačne izveštaje o mortalitetnoj statistici.

\section{ZAKLJUČAK}

U posmatranom periodu zapažen je porast stope broja umrlih stanovnika Srbije sa nepoznatim uzrokom smrti, uz naročito visoke stope u 2009. i 2016. godini. Uporednom analizom, utvrđeno je da su R00-R99 dijagnoze više zastupljene u mortalitetnoj statistici Srbije, u odnosu na Sloveniju i Hrvatsku, a manje u odnosu na Severnu Makedoniju. Potrebne su hitne intervencije u cilju poboljšanja kvaliteta podataka o osnovnom uzroku smrti u potvrdama o smrti, kako bi se povećalo poverenje u njihovu tačnost $\mathrm{i}$ kako bi ti podaci bili primarni dokazi na kojima se zasnivaju epidemiološka istraživanja i zdravstvene politike. Ovo istraživanje je omogućilo da se predstavi šira slika kvaliteta šifriranja podataka o osnovnom uzroku smrti u potvrdi o smrti, na regionalnom nivou.

\section{Izjave zahvalnosti}

Istraživanje je deo master teze iz oblasti javnog zdravlja dr Nataše Rosić, pod naslovom „Zastupljenost nepoznatih i loše definisanih uzroka smrti u mortalitetu stanovnika Srbije: implikacije na unapređenje kvaliteta mortalitetne statistike" odbranjene na Medicinskom fakultetu Univerziteta u Beogradu (mentor: prof. dr Milena Šantrić Milićević; Beograd, septembar 2018.)

Sukob interesa: Nije prijavljen. and individual diagnoses, as well as by the source of data in the death certificates), and then to perform a comparative analysis against the diagnoses of the medical examiners, in order to better understand the problem and define the target interventions. Health care institutions, especially hospitals, are a common source of population mortality data, by age, sex, and cause. These statistical data are important markers of the quality of hospital care and provide for necessary investments, for both national and local health care policies. Continued training is necessary, with respect to the appearance, content and proper coding of data on the cause of death, both for doctors in health care institutions and for medical examiners, who are involved in filling out death certificates. It is also very important that decision makers in the health care system should recognize the significance of precise and quality data on mortality, which is why investing into the strengthening of the vital registration system is necessary, in order to achieve improvement at all levels, in the sense of properly coded underlying causes of death and the incorporation of these data into final reports on mortality statistics.

\section{CONCLUSION}

In the observed period, an increase in the death rate of Serbian citizens with unknown cause of death has been noted, with exceptionally high rates in 2009 and 2016. Comparative analysis has shown that R00-R99 diagnoses are more present in the mortality statistics of Serbia, as compared to Slovenia and Croatia, and less, as compared to North Macedonia. Urgent interventions are necessary in order to improve the quality of data on the underlying cause of death in death certificates, with the aim of improving the trust in their accuracy and providing for these data to be the primary proof which epidemiological research and health policies are based on. This research has provided a broader view of the quality of coding data on the underlying cause of death in death certificates, at the regional level.

\section{Acknowledgements}

The study is a part of the master thesis in the area of public health by Dr. Nataša Rosić, titled: The participation of unknown and ill-defined causes of death in the mortality of the population of Serbia: implications for the improvement of mortality statistics quality, defended at the Faculty of Medicine of the University of Belgrade (mentor: Professor Milena Šantrić Milićević, PhD; Belgrade, September 2018.)

Conflict of interest: None declared. 


\section{PRILOG 1}

Grupa XVIII u MKB-X, Simptomi, znaci ipatološki klinički nalazi neklasifikovani na drugom mestu sadrži trinaest podgrupa, a to su:

R00-R09 Simptomi i znaci sistema za krvotok i sistema za disanje

R10-R19 Simptomi i znaci sistema za varenje i trbuha

R20-R23 Simptomi i znaci kože i potkožnog tkiva

R25-R29 Simptomi i znaci nervnog sistema i mišićno-koštanog sistema

R30-R39 Simptomi i znaci mokraćnog sistema

R40-R46 Simptomi i znaci poimanja, čulnog opažanja, emocija i ponašanja

R47-R49 Simptomi i znaci poremećaja govora i poremećaja glasa

R50-R69 0pšti simptomi i znaci

R70-R79 Patološki nalazi krvi, bez dijagnoze

R80-R82 Patološki nalazi mokraće, bez dijagnoze

R83-R89 Patološki nalazi drugih telesnih tečnosti, supstanci i tkiva, bez dijagnoze R90-R94 Patološki nalazi kod dijagnostike i funkcionalnih ispitivanja, bez dijagnoze R95-R99 Neoznačeni i nepoznati uzroci smrti

\section{LITERATURA / REFERENCES}

1. Mathers $C D$, Ma Fat $D$, Inone M, RoCh, LopeAD. Counting the dead and what they died from: an assessment of the global status of cause of death data. Bulletin of the World Health Organization 2005: 83:(3).

2. Ylijoki-Sørensen S, Sajantila A, Lalu K, Bøggild H, Lier Boldsen J, Thorup Boel LW. Coding ill-defined and unknown cause of death is 13 times more frequent in Denmarkthan in Finland.Forensic Science International 2014;(244): 289-94.

3. Becker TM, Wiggins CL, Key CR, Samet JM. Symptoms, signs, and ill-defined conditions: a leading cause of death among minorities.Am J Epidemiol. 1990;131(4):664-8.

4. Kulhánová I, Menvielle G, BoppM, Borrell C, Deboosere P, Eikemo TA, et al. Socioeconomic differences in the use of ill-defined causes of death in $16 \mathrm{Eu}$ ropean countries. BMC Public Health 2014;14:1295.

5. Priručnik o popunjavanju Potvrde o smrti, Projekat: Unapređenje kvaliteta podataka mortalitetne statistikeu BiH, dostupno na: http://www.zzjzfbih. ba/wpcontent/uploads/2017/03/Priru\%C4\%8Dnik- 0-popunjavanju-potvrde-0-smrti.pdf., pristupljeno 28. 03. 2018.

6. Danilova I, Shkolnikov VM, Jdanov DA, Meslé F, Vallin J. Identifying potential differences in cause-of-death coding practices across Russian regions. Popul Health Metr. 2016 Mar 22;14:8.

7. Ozdemir R, Rao C, Ocek Z, Dinc Horasan G. Reliable mortality statistics for Turkey: Are we there yet? BMC Public Health. 2015 Jun 10;15:545. doi: 10.1186/s12889-015-1904-1.

8. Međunarodna statistička klasifikacija bolesti i srodnih zdravstvenih problema DESETA REVIZIJA Knjiga 2, Priručnik za upotrebu, dostupno na: http://www. batut.org.rs/download/MKB102010Knjiga2.pdf, pristupljeno: 07. 03. 2018.

9. WHO, Certification, dostupno na: https://apps.who.int/classifications/apps/ icd/icd10training//CD-10\%20Death\%20Certificate/html/index.html, pristupljeno 28. 05. 2021.

10. WHO Application of ICD-10 for low-resource settings initial cause of death collection, The startup Mortality Lis t(ICD-10-SMoL), dostupno na: http:// www.who.int/healthinfo/civil_registration/ICD_10_SMoL.pdf, pristupljeno: 10.03 .2018

\section{APPENDIX 1}

Group XVIII in the ICD-X, Symptoms, signs and abnormal clinical and laboratory findings, not elsewhere classified comprises the following 13 subgroups:

R00-R09 Symptoms and signs involving the circulatory and respiratory systems

R10-R19 Symptoms and signs involving the digestive system and abdomen

R20-R23 Symptoms and signs involving the skin and subcutaneous tissue

R25-R29 Symptoms and signs involving the nervous and musculoskeletal systems

R30-R39 Symptoms and signs involving the urinary system

R40-R46 Symptoms and signs involving cognition, perception, emotional state and behavior

R47-R49 Symptoms and signs involving speech and voice

R50-R69 General symptoms and signs

R70-R79 Abnormal findings on examination of blood, without diagnosis

R80-R82 Abnormal findings on examination of urine, without diagnosis

R83-R89 Abnormal findings on examination of other body fluids, substances and tissues, without diagnosis

R90-R94 Abnormal findings on diagnostic imaging and in function studies, without diagnosis

R95-R99 III-defined and unknown causes of mortality

11. Međunarodna statistička klasifikacija bolesti i srodnih zdravstvenih problema Deseta revizija. Knjiga 1. Tabelarna lista. Izdanje 2010., dostupno na: http://www.batut.org.rs/download/MKB102010Knjiga1.pdf , pristupljeno: 07. 03. 2018.

12. Republika Srbija. Zakon o zdravstvenoj zaštiti „Sl.glasnik RS“, br. 107/05., dostupno na: http://www.zdravlje.gov.rs/tmpmz-admin/downloads/zakoni1/ zakon_zdravstvena_zastit.pdf, pristupljeno: 06. 03.2018.

13. Republika Srbija. Zakon o matičnim knjigama „Sl. glasnik RS, br.20/09., dostupno na: http://www.trzistesrbije.com/ntrus/law/280199069995433.pdf, pristupljeno: 03. 2018.

14. Republika Srbija. Zakon o sistemu statističkih istraživanja. "SI. glasnik RS", br. 104/2009., dostupno na: http://demo.paragraf.rs/demo/combined/0ld/t/ t2009_12/t12_0206.htm, pristupljeno: 01.03. 2018.

15. Republika Crna Gora. Uputstvo za popunjavanje potvrde o smrti, dostupno na: http://www.monstat.org/userfiles/file/demografija/upustva-umrli\%20 sve.pdf, pristupljeno: 27. 02. 2018.

16. Republika Hrvatska. Priručnik o popunjavanju potvrde o smrti, dostupno na: https://www.hzjz.hr/wp-content/uploads/2013/11/prirucnik.pdf, pristupljeno: 27. 02. 2018.

17. Republika Hrvatska. Zakon 0 državnim maticama, dostupno na: https:// www.hzjz.hr/sluzba-epidemiologija-prevencija-nezaraznih-bolesti/ odjel-za-mortalitetnu-statistiku/, pristupljeno: 27. 02. 2018.

18. Državen zavod za statistika, MAKStat Database, Republika Makedonija, dostupnona:http://makstat.stat.gov.mk/PXWeb/pxweb/en/MakStat/MakStat__ Naselenie_Vitalna/125_Vit_mk_Umreni_ang.px/?rxid=930e77c1-25ff4c46-905d-5dda13edd01f, pristupljeno: 12.03.2018.

19. Republika Severna Makedonija. Podaci o mortalitetu stanovnika Republike Makedonije, dostupno na: http://makstat.stat.gov.mk/PXWeb/pxweb/ en/MakStat/MakStat_Naselenie__Vitalna/125_Vit__mk_Umreni_ang. px/?rxid=46ee0f64-2992-4b45-a2d9-cb4e5f7ec5ef, pristupljeno: 10.03. 2018.

20. Republika Slovenija. Zdravniško poročilo o umrli osebi, Nacionalni institut za javno zdravlje, Ljubljana, Slovenija, dostupno na: https://podatki.nijz.si/docs/3a_ Umrli_Metodolo\%(5\%A1ka_pojasnila_NIJZ.pdf, pristupljeno: 10.03. 2018. 
Rosić N.

21. Podaci o mortalitetu stanovnika Republike Slovenije, dostupno na: http:// pxweb.stat.si/pxweb/dialog/statfile2.asp- , pristupljeno: 12.03. 2018.

22. Özdemir R, Rao C, Öcek Z, Dinç Horasan G. Reliable mortality statistics for Turkey: Are we there yet? BMC Public Health. 2015 Jun 10;15:545.

23. Danilova I, Shkolnikov VM, Jdanov DA, Meslé F, Vallin J. Identifying potential differences in cause-of-death coding practices across Russian regions. Popul Health Metr. 2016 Mar 22;14:8.
24. The Impact of the Implementation of IRIS Software for ICD-10 Cause of Death Coding on Mortality Statistics in Scotland, dostupno na: https://www. nrscotland.gov.uk/files/statistics/vital-events/impact-of-implementation-iris-for-icd.pdf, pristupljeno: 06.03.2018.

25. Center for Disease Control and Prevention, National Vital Statistics System, dostupno na: https://www.cdc.gov/nchs/nvss/deaths.htm, pristupljeno: 20.03.2018.

26. Tin Oung M, Richter K, Prasartkul P, Tangcharoensathien V. Myanmar mortality registration: an assessment for system improvement. Popul Health Metr. 2017 Sep 25;15(1):34. 